Geografia e Ordenamento do Território, Revista Electrónica

Centro de Estudos de Geografia e Ordenamento do Território

http://cegot.org

ISSN :2182-1267

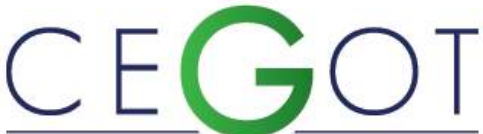

Centro de Estudos de Geografia e Ordenamento do Território
CARDOSO, VASCO

CEGOT/ I2ADS

Avenida Rodrigues de Freitas, 265, 4049-021, Porto, Portugal vcardoso@fba.up.pt

\title{
O passado de alguns futuros já desejados na forma urbana
}

\author{
The past of some futures once desired in urban form
}

Referência: Cardoso, Vasco (2016). O passado de alguns futuros já desejados na forma urbana. Revista de Geografia e Ordenamento do Território (GOT), n. 10 (dezembro). Centro de Estudos de Geografia e Ordenamento do Território, p. 71-94, dx.doi.org/10.17127/got/2016.10.004

\section{RESUMO}

Desafiado pelo tema do colóquio "A Geografia na Construção do Futuro Desejado"1, pretendeu-se expor uma metodologia de investigação em Morfologia Urbana e Urbanismo e tentar contribuir para a reflexão sobre a pertinência do estudo diacrónico de futuros desejados.

Seguiu-se o nascimento e a maturação das opções urbanísticas da Câmara Municipal do Porto, expressas em projeto aprovado e em forma urbana, valorizando-se, assim, a forma logo desde a sua primeira expressão gráfica oficial, antes de ser tangível. Esse percurso do sonho à realidade é, também ele, já, de modelação da forma, pelo que de confrontos o sonho foi tendo com a circunstância. Distribuindo pelo tempo (1936-1974) e pelo espaço (concelho do Porto) os exemplos organizados - parcelas de futuros desejados - registaram-se assim 4 pontos de reflexão sobre o passado de alguns futuros já desejados na forma urbana.

Palavras-chave: Morfologia urbana; Urbanismo; Cartografia histórica; Plano; Planeamento

\footnotetext{
${ }^{1}$ Colóquio Internacional em Língua Portuguesa organizado pela Linha de Políticas Públicas, Planeamento e Ordenamento do Território do Centro de Estudos de Geografia e Ordenamento do Território (CEGOT), que decorreu no Porto, nos dias 13 e 14 de outubro de 2016.
} 


\begin{abstract}
Encouraged by the conference theme "Geography in the Construction of Desire Future", we aim to expose a research methodology on Urban Morphology and Urbanism. A contribution to the reflection on the relevance of diachronic studies of the desired futures it's also a goal. The Porto City Council urban criteria's birth and maturation was the researched theme. To that purpose, we focus our attention on its expression from the approved document to tangible urban form. As the confrontation between form and form to be occurred, the journey from dream to reality becomes a modelling process. Distributing the organized examples - desired future's fragments - through time (1936-1974) and space (Porto) we established 4 reflection starting points on the past of some futures once desired in urban form.
\end{abstract}

Key Words: Urban Morphology, Urbanism, Historical Cartography; Plan; Urban Planning

\title{
1. Introdução
}

Com o presente texto procura-se fazer um novo exercício de reflexão sobre os, e a partir dos, resultados de investigação numa tese de doutoramento defendida em 2015. O trabalho de investigação referido analisou a produção da forma urbana no Porto, buscando a morfogénese dos espaços que, de facto, mais atenção receberam das políticas públicas. Essas ganham relevo pela coincidência do período escolhido com os alvores das leis sobre planos de urbanização em Portugal, e com o período de início do governo de Salazar, o que conferiu a esse tempo a característica de alguma linearidade ao processo de decisão política. Inclusive, nos primeiros anos da ditadura, esta arvorou-se pela senda da definição de uma norma morfológica identitária, à semelhança daquilo de que os fascistas e os nazis mais próximo ficaram.

$\mathrm{Na}$ linha do que tinha acontecido no século XIX com os chamados "projetos de empréstimo", os planos de urbanização lançados com Duarte Pacheco, em 1938, acabaram por, no resultado, descender dessa prática. A investigação de doutoramento (V. CARDOSO, 2015, a) em que este texto se filia, através do estudo das atas das reuniões da Câmara, de alguma troca de correspondência oficial com os serviços do Estado, da inventariação, catalogação, localização, classificação e sistematização de perto de 1000 projetos municipais, e dos quais se estudou cerca de metade, consolidaram aquele quadro. Em estudo anterior (V. CARDOSO, 2011), examinara-se o perfil dos dois últimos "projetos de empréstimo" prévios à lei de $1864^{2}$, de 1852 e 1865 (com a primeira versão de 1863, culminando na sua reformulação ao regulado pela dita lei), arrolavam uma série de obras de melhoramentos, aberturas de ruas e obras de embelezamento.

Os planos gerais de urbanização no Porto resultaram muito mais como que pontos de situação, registo compilado daquilo que já corria em projetos locais. A imposição de qualquer desenho predeterminado ou preconcebido sobre o território e a sociedade ficou assim mais plástica. Esses

\footnotetext{
${ }^{2}$ Decreto-lei de 31 de dezembro de 1864, publicado a 19 de janeiro de 1865.
} 
planos gerais de urbanização encadearam um conjunto de projetos de obras a executar, anteriormente projetadas nos serviços municipais ou ministeriais, e não advieram da elaboração de um único enunciado global e original de um futuro desejado, fruto de um debate teórico entre modelos. No entanto, houve a ancoragem a alguns desses modelos, dos quais se encontram exemplos de clara expressão formal. Foram vários os exemplos de paradigmas de urbanização estrangeiros, contudo foram apenas estimados quando servindo ao modelo do Estado que nunca existiu, efetivamente (P. V. ALMEIDA, 2002) - mas cujo ideal contaminou -, resultando desse modo em metamorfoses ou, até anamorfoses, próprias para o contexto de acolhimento.

Porém, de facto, o futuro foi desejado dia a dia, local a local, no confronto entre poder político municipal e nacional, sob o complexo problema da expropriação e posse de terrenos para a expansão urbana almejada. Soma-se ao problema, não terem sido lineares os efeitos esperados da capacidade atribuída aos planos de urbanização, em se constituírem como documentos legais bastantes para operacionalizar as expropriações, fundamentais à expansão urbana pretendida.

Este quadro da concretização daquilo que se desejou para os planos de urbanização e o seu caminho até se chegar àquilo que, de facto, reverteu em forma urbana, é estudado pela Morfogénese. 0 estudo da Morfogénese e da sua circunstância, sob uma perspetiva multiescalar e multitemporal, mostrou importância na definição de padrões contribuintes para o entendimento do urbanismo e da forma urbana do Porto, do período analisado: 1936 a 1974. O tempo e a mediação de todas as variáreis reais determinam a evolução da forma, desde o modelo, passando pelos diferentes projetos e terminando na sua concretização, na maioria dos casos faseada ou territorialmente afastada.

O estudo das propostas de intervenção urbana de origem municipal e de abrangência territorial mais reduzida pôde ser outra prestação para o entendimento da forma urbana do Porto, a partir da sua morfogénese. Por essas propostas de intervenção terem sido lançadas pelos planos gerais, mas, sobretudo, na sua maioria, por terem sido tributárias desses, ganham uma importância central.

\section{Metodologia}

No estabelecimento da metodologia para os estudos levados a cabo foi importante logo na partida a consideração tida pela experiência de M. BASTO (1936): “... Livros de Actas... Aí encontra o investigador elementos de primeira ordem, tam sugestivos como exactos e numerosos, para o conhecimento da evolução histórica do Pôrto". Ainda, mais fino, sublinhou o autor, M. BASTO (1946), que "A leitura dos velhos Relatórios da Gerência...fornece informações muito curiosas, para quem tiver prazer ou interesse em conhecer a evolução e os progressos do Porto...". Mas se a fonte escrita tem a importância do dado por extenso e, neste caso, para o bem e para o mal, do dado oficial, foram também procurados meios de contraprova. Para tal, seguiu-se a proposta de M. G. FERNANDES (2005) de ganhar conhecimento do “...caminhar pelas cidades...[e na]...busca de meios de observação, quer escritos, quer cartográficos, dos cenários passados ...[como]... imprescindível 
para a interpretação da cidade...". Nesse sentido da aferição, foram ainda relevantes alguns documentos escritos, troca de correspondência entre o poder político local e o nacional. Mas, também mereceram estudo cuidadoso, quer o corpo legal em vigor, quer ainda documentação noticiosa atinente.

Para a consecução dos objetivos abordados e apoiado na estrutura metodológica apresentada delineou-se o caminho por duas fontes primárias essenciais. Em primeiro lugar, dissecaram-se as atas das reuniões decisórias do poder municipal, entendendo esse como o autor, a estudar, da forma urbana que é e a que poderia ter sido. Mas, além dessas reuniões dois outros documentos se perfilaram: um com os desafios - Planos de Atividade, para o ano seguinte - e outro com a avaliação - Relatórios de Contas da Gerência, do ano anterior. Apesar de um autor coletivo aceite, considerouse, contudo, a forma ditada pelo Código Administrativo, de 1936-40, para a seleção do Presidente da Câmara, cujo perfil de governação foi também uma marca relevante do pensamento urbanístico havido na edilidade. Nesse sentido, na investigação analisaram-se 7 presidências (integrando nessas as respetivas presidências interinas), 7 períodos, procurando entender contextos e implicações do seu perfil na morfogénese urbana: a que veio a ser e a que poderia ter sido.

Daquela investigação conseguiu-se a chave para o acesso à outra fonte primária: os projetos aprovados nas reuniões de Câmara - orientadores da ação sobre a forma urbana, na cidade e para a sua expansão. No seguimento, procedeu-se a um levantamento, estudo e uma classificação desses projetos. A dinâmica temporal e os constrangimentos ocorridos para tornar tácteis os desejos resultaram na aprovação de vários projetos ao longo do tempo, para um mesmo local, pensado, ora per si, ora integrado em âmbitos mais vastos. A necessidade de referenciação espacial de cada projeto foi o primeiro parâmetro fundador de uma organização e classificação dos dados, obrigatoriamente em constante mutação. $\mathrm{O}$ trabalho foi várias vezes afinado, pois as designações dos locais alteraram ao longo do tempo, e nem sempre coincidiam as designações dadas com o local de facto tratado.

Por outro lado, a falta de um quadro legal estável durante o período, no que respeita às tipologias de projetos - designações e conteúdos -, redundou no levantamento de projetos com títulos muito variados e conteúdos que demasiadas vezes não correspondem ao que atualmente poderemos entender dessas designações oficiais. Assim, foi necessário criar uma nova gama tipológica, afeta ao âmbito de cada projeto. Deste modo, dos cerca de mil projetos classificados, foram estudados em pormenor perto de metade, entre escolhidos e disponíveis, dos depositados em divisões do município. Alguns projetos de intervenção tinham, no entanto, caraterísticas comuns que, coadjuvadas pelas inscrições em ata de reunião de Câmara, no que a esses respeitava, permitiam estimar com segurança credível o tipo a que cada um pertenceria (caso das retificações simples de alinhamentos; os projetos em maior número). Após um olhar que se quis minucioso, para a proposta de aprovação, a memória descritiva e justificativa e, os desenhos, especialmente para a planta de urbanização, foi possível estabelecer os critérios estruturantes da nova gama tipológica. Esta acabou por ter 4 categorias, após tentativas anteriores com graus de variação muito específicos, mas pouco operativos. Fixaram-se então os seguintes tipos: 
- "Arranjos" - alinhamentos e retificações e regularizações de cérceas, implantações e pavimentos, alargamentos de espaço público, melhoramentos, embelezamentos e beneficiações;

- "Aberturas" - aberturas e prolongamentos de ruas e praças;

- "Projetos" - projetos de pormenor de planos de urbanização, nomeadamente projetos de urbanização consequentes da implantação de edifícios ou espaços públicos, projetos de urbanização de pequenas áreas na sequência da iniciativa privada, talhamentos e renovações de áreas;

- "Planos" - planos de urbanização, planos parciais de urbanização, alterações a planos, alterações a zonamentos.

Esta leitura temporal, necessariamente, multiescalar e pluridimensional, conduziu a uma taxinomia e foi tomada como a raiz da análise morfogenética havida. O próprio processo de inventariação foi um processo de aumento de conhecimento, por si.

\section{Metodologia e alguns resultados}

No corolário do trabalho empírico, elaboraram-se gráficos para a interpretação da distribuição temporal das aprovações e 7 plantas, uma por presidência, tendo-se feito uma análise caso a caso da distribuição territorial das aprovações.

Assim, posteriormente, a propósito de uma primeira reflexão (V. CARDOSO, 2015,b), sobre e a partir dos estudos de doutoramento, construíram-se 4 plantas de síntese a partir dos gráficos e das plantas acima mencionadas: uma análise guiada pela quantidade e efeitos da produção do autor Câmara e não por produção projetual de cada edil. Estas plantas permitiram esboçar 4 cidades que o Porto poderia ter sido, captando 4 momentos, diferentes do fixado nos planos gerais de urbanização, como referido no início deste texto. São, no fundo, 4 futuros desejados.

Em primeiro lugar, pelo gráfico 1 conseguem-se destacar os períodos de maior e menor

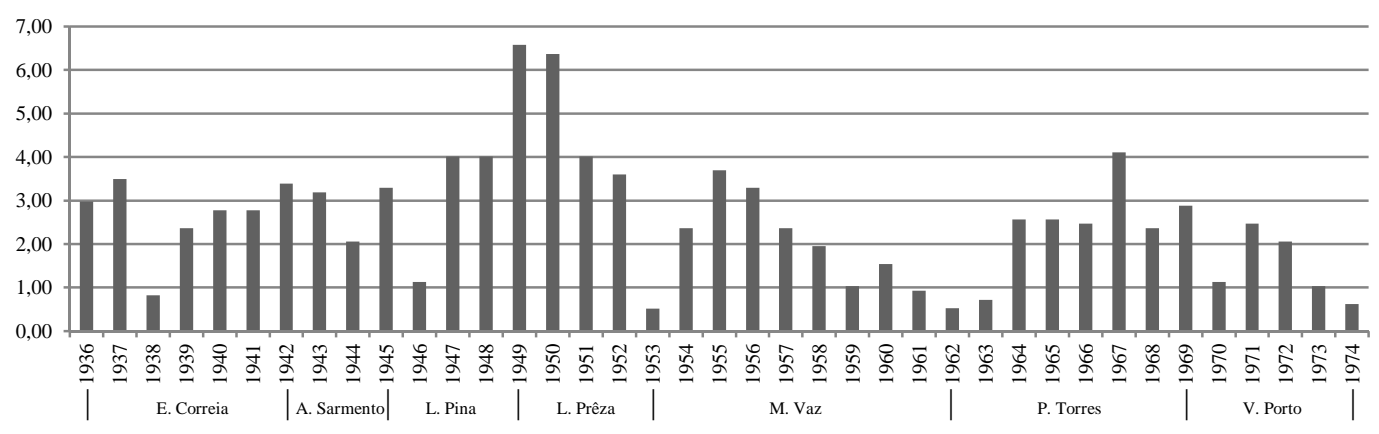

Gráfico 1 - Do universo das aprovações, a percentagem global de obras por ano. Fonte: Vasco Cardoso, 2016. 
produtividade, o que, concatenado com a informação retirada das atas das reuniões da Câmara e atentos ao quadro nacional, permite aclarar a discrepância entre a formulação do desejado no projeto de urbanização mais circunscrito e aquilo que era registado nos planos gerais de urbanização.

Nesta distribuição das aprovações por ano, sobre o intervalo de cada presidência, aponta-se decréscimo no número de aprovações nos anos de 1938, 1946, 1953, de 1961 a 1963 e em 1974.

As alterações nos serviços municipais motivadas pelas exigências do novo Código Administrativo, entrado em vigor em 1938, explicaram em parte o decréscimo assinalado. Por outro lado, a criação do Gabinete de Estudos do Plano Geral de Urbanização, para resposta aos Decreto-Lei n.․ 24802, de 21 de dezembro1934, e Decreto-Lei n.o 28995, de 14 de fevereiro1938, deverá explicar a outra parte.

Para o decréscimo de 1946 relevou a reorganização que Luís de Pina operou nos serviços do Plano, após a imputação de críticas pela demora na conclusão do plano geral de urbanização e que levaram à entrada de Almeida Garrett para os serviços técnicos afetos. Na verdade, os serviços colaboravam em várias frentes, sob uma base legal ${ }^{3}$ que procurava enquadrar as contingências da nova atividade projetual, dentro e fora da Câmara, como com os serviços do Estado no Plano Regional do Porto.

O intervalo entre 1952 e 1954, entre a aprovação municipal do Plano Regulador e a sua homologação, será marcado pela mudança de presidência, numa altura em que começava a haver conclusões para a habitação económica de iniciativa municipal, sendo que o novo presidente, Machado Vaz, iria consolidando aqueles na conformação do Plano de Melhoramentos de 1956. O novo edil apostara nos estudos prévios à ação. A fixação de um plano geral de urbanização, o Plano Regulador, deu a base para novos estudos de urbanização que, de facto, vinham acontecendo. Os estudos não só contemplaram o problema da habitação, mas uma série de planos de urbanização setoriais pela margem da cidade. Estes seriam logo desde 1957 continuados e abraçados pelo contratado Robert Auzelle, construiriam em grande parte a revisão do Plano Regulador. Terá sido esta estratégia a responsável primeira pelo decréscimo no número de aprovações.

De modo similar, o período de 1961, ano de início da guerra colonial, a 1963, ano de aprovação do Plano Director, o novo plano geral, coincidiria com uma diminuição do número de aprovações de ações urbanísticas. Também durante este intervalo houve mudança para a presidência de um governante que redirecionaria a atenção para a cultura e a melhoria das condições sociais da população, sem, contudo, abandonar os estudos de novos, ou revistos, planos parcelares e tendo como tarefa hercúlea a conclusão bem-sucedida do Plano de Melhoramentos, 1956-1966.

Para o final do período, há que assinar o impacto da crise mundial do petróleo e os efeitos da guerra colonial, como responsáveis pelo menor número de aprovações. Mas, pelo lado municipal, é também relevante o descrédito que os bairros de habitação económica iam merecendo nas reuniões da Câmara, muito por causa da desadequação do modo de vida dos seus moradores face ao

\footnotetext{
${ }^{3}$ O Decreto-Lei n. $~ . ~ 35931$, de 4 de novembro de 1946, conferiu força legal ao anteplano: permitiria o AntePlano Regulador, para o qual foi contratado Almeida Garrett.
} 
estimado pelos promotores. Não é também de descontar para o cúmulo desse descrédito o fator atrativo que os bairros exerceram sobre pobres de outros concelhos, muitos dos quais construíam barracas pela periferia da cidade. Assim, e apesar de novas edições, o Plano de Melhoramentos desvaneceu. Pelo contrário, o interesse pela Ribeira-Barredo como uma nova preocupação com a dimensão social do problema ganhara posição central na ação urbanística do município.

Vistos os pontos baixos no número de aprovações de projetos urbanísticos, no fundo alguns dos reveses que moldaram vários futuros desejados, importa referir os principais momentos onde o quadro foi o inverso. Estes períodos de maior produtividade estão associados a uma maior estabilidade e a tempos concentrados de finalização de projetos. São esses momentos dados para a definição dos critérios sustentadores das 4 plantas de distribuição das quantidades e tipos de intervenções urbanísticas aprovadas e que à frente serão expostas como ilustrativas das linhas gerais de 4 futuros desejados.

Mas, introduzindo a variável tipo de intervenção aprovada, das quatro estabelecidas, olha-se agora para os números globais da análise sob esse prisma. Assim, salienta-se que praticamente metade $(48,6 \%)$ dos projetos de obras ou urbanização caíram dentro do primeiro tipo. Reveladora será depois a evolução da distribuição espacial desses ao longo do tempo do estudo. Verifica-se ainda que cerca de um terço $(35,5 \%)$ dos documentos urbanísticos aprovados referem-se ao que poderão ser entendidos como planos urbanísticos de pormenor. Por fim, deve referir-se que grandes planos de urbanização, sublinhe-se, não os gerais de urbanização, como Planos Diretores Municipais, perfizeram apenas um total de $2,5 \%$ da documentação identificada e estudada. Estes dados permitem antolhar para uma conclusão de que a intervenção e expansão da cidade, numa época de lançamento e maturação dos primeiros planos de urbanização devidamente legislados, ocorreu mais por avanços e transformações de abrangência territorial mais reduzida, do que por peças de grande rasgo e comprometimento. Esta previsão de conclusão ratificar-se-ia no trabalho também pelo teste da distribuição espacial de cada uma das peças e do gráfico.

É agora importante rever outro gráfico que expõe a distribuição daqueles tipos pelo tempo. Desse retira-se, logo à partida, a clara instalação da prática do plano que foi acontecendo nos serviços.

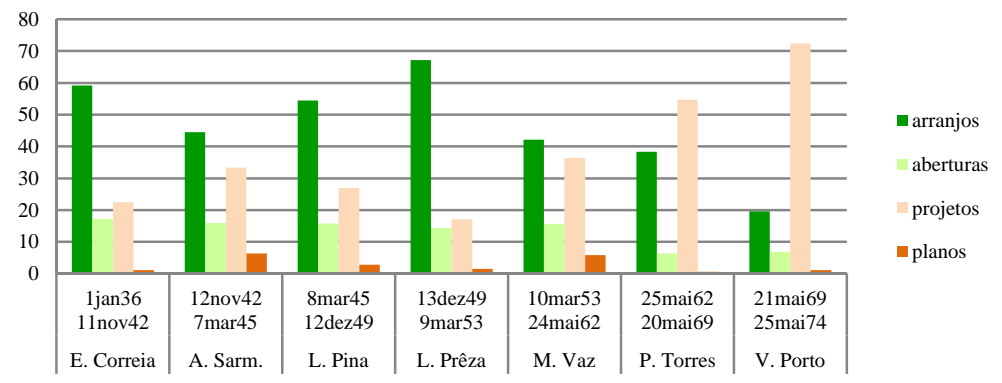

Gráfico 2 - Do universo das aprovações de cada presidência, percentagem de cada tipo por presidência, Fonte: Vasco Cardoso, 2015, corresponde ao gráfico n. 3 da tese de doutoramento. 
A presidência de Albino Machado Vaz marca a troca de uma maioria de projetos de tipo "arranjos" para o crescimento de ação urbanística dominada por aprovações de ações dentro do tipo "projetos". Ou seja, uma série de condições concentraram-se desde o início daquela presidência e puderam ser o fator decisivo para uma mudança: de uma prática baseada em ações urbanísticas pontuais e de pouca envergadura, a par de um enorme esforço na elaboração de vastos planos de urbanização de abrangência territorial grande, para uma época em que o planeamento urbanístico parcelar foi dominante, numa primeira fase ligado a equipamentos de iniciativa pública e depois a empreendimentos, como Ihes chamou J. M. P. OLIVEIRA (1973), de iniciativa privada. Em primeiro lugar, o crescimento após o final da II Guerra Mundial trouxe investimento, marcado em Portugal pelos Planos de Fomento, promotores de iniciativa estatal, tendo suportado muitos dos planos de pormenor referidos. Por outro lado, alguns documentos legais apareceram finalmente, como o Regulamento Geral de Edificações Urbanas (REGEU), de 1951, que enquadraram muita da atividade urbanística. Em último lugar, a aprovação do primeiro plano geral de urbanização para o Porto terá tido a sua influência, mas mais como registo coletor de tudo aquilo que vinham desejando para a forma urbana e urbanismo no Porto e como instrumento legal facilitador, não tanto como uma imposição que viesse a ser seguida estritamente.

Do gráfico 2 interessa ainda sublinhar outro aspeto que caracteriza este período de 1936-1974. Trata-se da distribuição do tipo "planos" pelo tempo. Logo pelos inícios da década de 1940 surgem os vastos e ambiciosos planos para o Campo Alegre e para a Zona Industrial de Ramalde, são futuros desejados em grande escala e investimento. São os primeiros grandes planos e nasceram para dar resposta ao problema da travessia do Douro, e do Porto, pela Arrábida e do acesso ao Porto a Leixões, promovendo ao mesmo tempo espaço para a expansão da cidade para poente. De facto, foram a parte avançada do plano geral de G. Muzio e que não chegou a ser aprovado. Em complemento a estes, fornecendo oferta para populações de menores rendimentos, aprovaram durante a presidência de Albano Sarmento outros dois planos mais modestos para a Areosa e o Amial, nas fraldas dos terrenos condicionados pelos estudos, iniciados em 1936, de urbanização provocada pela implantação do Hospital Escolar, a norte. Também nesta época aprovavam duas ações no seguimento dos "planos" de renovação e articulação dos espaços influenciados pela abertura da Avenida dos Aliados.

O outro período de aumento na produção de "planos" integra o tempo da presidência de Machado Vaz. Na esteira do Plano Regulador, o presidente promoveu um tempo de estudos que levaram ao Plano de Melhoramentos, com uma série de conjuntos de blocos de habitação económica dispersos pelas freguesias pericentrais ${ }^{4}$ e alguns planos parcelares de urbanização. Desde logo, são exemplo desses últimos o novo plano do Campo Alegre e o da Zona Norte do Centro Comercial da Cidade do Porto, previstos no Plano de Melhoramentos, sendo o segundo um meio de resolver o problema dos espaços vazios deixados pela demolição das ilhas, problema maior na mira do Plano. Mas, desenvolveu ainda estudos para a Pasteleira e Nevogilde, na expansão da cidade pela margem do rio

\footnotetext{
4 "freguesias da meia coroa periférica" foi a designação dada no trabalho de doutoramento, na sequência de uma organização feita sobre o território do concelho, e que se utilizará nas plantas das páginas seguintes.
} 
até à Foz, continuando o Campo Alegre. Outros planos parcelares sairiam ainda dos serviços municipais coordenados por Auzelle até 1970, tentando preencher o território do concelho, na revisão do Plano Regulador e suporte do Plano Diretor, que se seguiu.

\section{Metodologia e esboço de 4 futuros já desejados na forma urbana}

Analisados os gráficos, propõe-se a apresentação das mencionadas 4 plantas, olhando para a dinâmica da distribuição espacial dos tipos dos projetos aprovados, tentando sublinhar algumas das aspirações principais, de caráter geral, que também aí estão presentes.

Contudo, e de facto, não só a quantidade de produção ou as distribuições dos tipos foram os únicos contribuintes para a definição das 4 plantas. O pensamento urbanístico da vereação, a coerência da linha formal, nomeadamente, pelas influências dos modelos morfológicos seguidos e dos técnicos contratados para a direção dos trabalhos, as relações entre o poder local e o poder central, ou mesmo as relações internas ao próprio Estado Novo, a influência dos aspetos centrais da política nacional e internacional, como as guerras, foram outros dos contribuintes considerados.

Conseguiram-se assim as próximas plantas, tomadas como correspondentes a 4 futuros desejados: 1 planta relativa no essencial à presidência E. Correia, com os meses finais da presidência anterior de A. Magalhães; 1 planta relativa ao prosseguido pelas seguintes três governações; 1 planta coincidente com a presidência de $M$. Vaz; e 1 planta relativa às presidências de $P$. Torres e V. Porto.

No final da apresentação de cada planta estará a ilustração de exemplo homólogo, numa área de expansão urbana, o Amial (rodeado na planta). A metodologia do trabalho de investigação de doutoramento impos a georreferenciação dos projetos consultados e que foram digitalizados pela Câmara Municipal do Porto, no apoio ao estudo. A sobreposição dos projetos a uma base visualmente mais neutra, com origem no Google Earth, permite uma leitura da forma urbana através do tempo. Isto é, um método que serve a Morfogénese. Para tal, tomaram-se referências como as do "New York City Historical Geographic Information Systems project" ${ }^{5}$ e de P. VETCH, et al. (2011). Um trabalho posterior, de mestrado (M. L. COSTA, 2015), no seio do CEGOT, montou uma base de dados em suporte informático, avançando mais um pouco no caminho das referências tomadas.

\footnotetext{
5 "New York City Historical Geographic Information Systems project", from The New York Public Library's Lionel Pincus and Princess Firyal Map Division.
} 


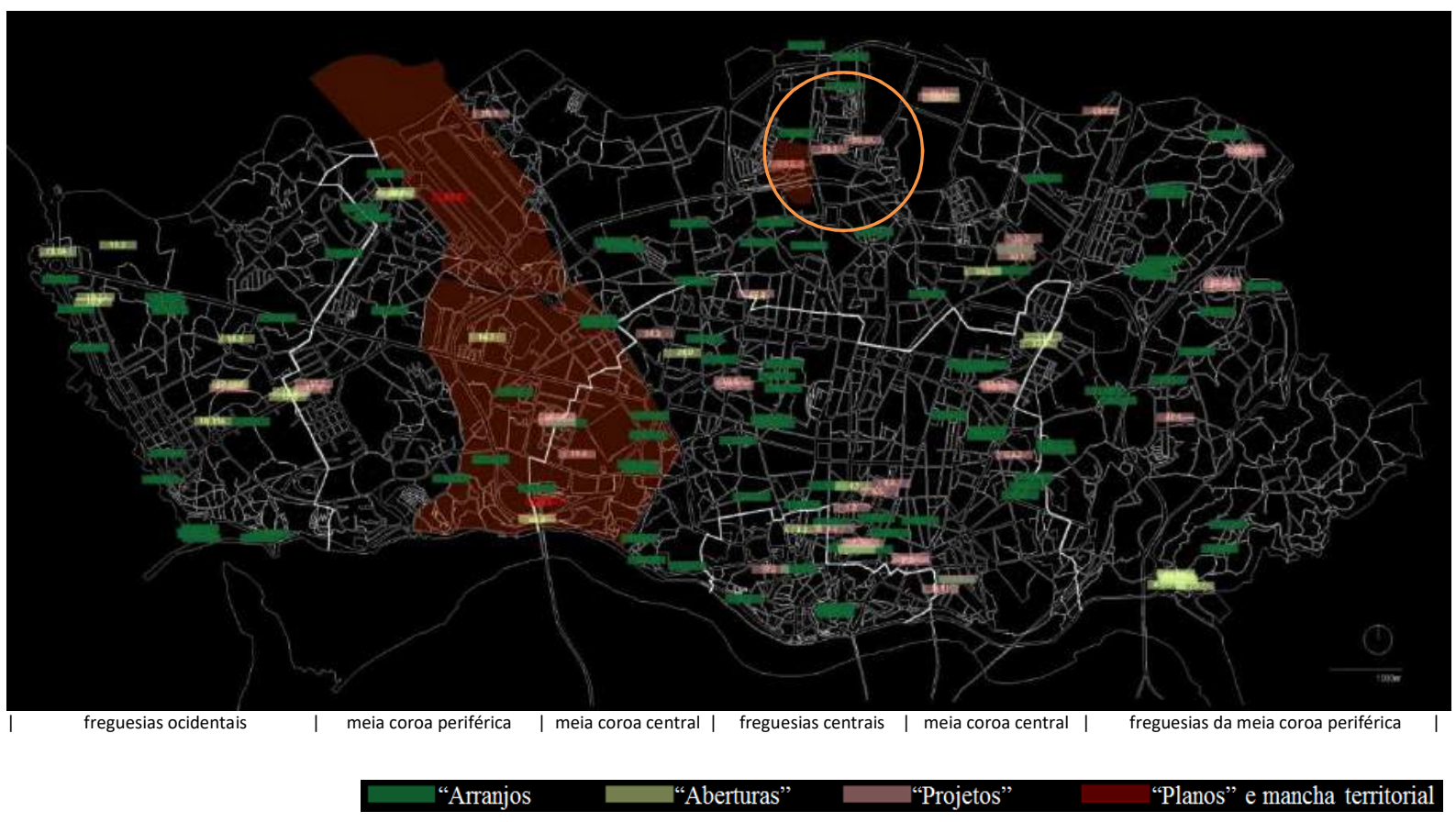

Planta 1 - Aprovações de propostas de ação urbanística no concelho do Porto, 1936-1942 (presidências de Alfredo Magalhães e Mendes Correia; “O Porto poderia ter sido uma cidade construída de planos de melhoramentos"). Fonte: Vasco Cardoso, 2015, sobre planta base da Câmara Municipal da Porto.

No período de arranque dos estudos para o plano geral de urbanização, em 1938, até à aprovação do primeiro plano para a urbanização do Campo Alegre e expansão da cidade na direção à Foz do Douro, os "arranjos" eram o tipo de intervenção urbanística com maior número de aprovações. Estas distribuíam-se por todo o concelho: eram a atividade urbanística predominante. A prática dos "projetos de empréstimo" para financiar retificações, melhoramentos ou embelezamentos, estendera-se, mesmo após a inovação trazida pelo Decreto-lei do Ministro das Obras Públicas João Chrysostomo de Abreu e Sousa, de 1864, já citado. Mas, foi também uma época para aprender a fazer planos, para estudar o território, e para se debaterem com as dificuldades do levantamento gráfico e geométrico do mesmo. Por outro lado, os investimentos estatais eram os únicos a ter o vigor para provocar intervenção urbanística efetiva. Citam-se desde a Ponte de D. Luís I, 1876, ao Hospital Escolar, lançado a 1936. A primeira estaria nos impulsos para o rasgamento da Avenida dos Aliados e, consequentemente, na raiz das intervenções conexas e posteriores. $\mathrm{O}$ segundo, pendente até depois da II Guerra Mundial, instalado já na bacia do Leça e voltado a norte, estaria na dinamização da expansão da cidade a norte.

Mas, duas iniciativas estatais fulcrais deste período são aqui consideradas e ilustrativas do futuro desejado para o centro e para a expansão.

No centro da cidade, pontuaram projetos para a reformulação em torno da Sé, para as celebrações do Centenários, e que, pelas demolições, dariam átrio à Sé e ao Paço do Bispo, onde se instalara a Câmara Municipal do Porto. Articulando com a resolução do problema dos acessos na continuação da Ponte de D. Luís I e da Ribeira, a Câmara debateu com o Estado o desejo deste em construir uma 
distribuição do trânsito em anéis a abraçar a cidade a diferentes diâmetros da testa da ponte, apontando o exemplo coevo inglês. Aqueles intersetariam com as antigas estradas, ou novas ruas, radiantes do centro da cidade. E, eram ainda atinentes projetos no centro, quer na Avenida dos Aliados, quer nas praças laterais e ruas criadas no decurso da execução da avenida. Por aí, cerziam os quarteirões com grandes volumetrias à face das novas ruas e praças rasgadas: vejam-se os casos das Praças de D. João I e D. Filipa de Lencastre e as Ruas de Sá da Bandeira e de Ceuta.

Na expansão para o Campo Alegre, atravessado pela via transversal ao Douro e ao Porto, e ligação ao Porto de Leixões, a partir do entroncamento com aquela transversal, G. Muzio deixaria dois planos.

A propósito daquelas duas iniciativas, A. GARRETT (1974) trouxe um documento para sustentar a sua informação sobre a estratégia desejada de urbanização: avançar em primeiro lugar para a expansão, onde os terrenos seriam mais amplos e baratos e, posteriormente, urbanizar e rentabilizar. Com os réditos previsíveis - tinham o exemplo bem-sucedido de Lisboa - investiriam na rutura para transformação e adequação do centro da cidade, visto como monumental.

Na disposição das formas sobre o território, a reunião de Câmara, de 14 de março de 1940, estabelecera o soalheiro e arejado planalto do Campo Alegre, sobranceiro ao Douro, para contemplar pessoas de rendimentos superiores: avenidas mais largas, com margens talhadas em lotes mais amplos, para assentarem volumetrias maiores. Por outro lado, a fim de prover oferta para população de menores rendimentos apontaram a Areosa e o Amial, a norte, na área determinada em 1937 como de influência urbanística do Hospital Escolar, respetivamente a nascente e poente deste. Eram áreas agrícolas viradas a norte e de terrenos mais húmidos. No primeiro local integraram a vontade da indústria lá presente em construir habitação para os seus operários. No segundo local previram a urbanização contígua a um dos bairros de Casas Económicas do Porto uma iniciativa estatal de disponibilizar habitação de baixo custo para algumas pessoas, nomeadamente as que por alguma razão ficavam anuentes com a orientação e prática política do Estado Novo. Em qualquer um dos dois exemplos para a expansão prosseguiriam no espírito da cidade-jardim.

E, em fevereiro de 1941, em visita decisiva do Ministro das Obras Públicas e Comunicações ao Porto ${ }^{6}$, ele, Duarte Pacheco, ratificara o quadro referido da orientação da urbanização no Porto. A planta 1 e as seguintes figuras 1 e 2 ilustram este futuro desejado.

\footnotetext{
6 "O Primeiro de Janeiro", ano 73., n. ${ }^{\text {os }}$ 40, pp. 1-3, e 41, pp. 1-3, de 11 e 12 de fevereiro de 1941, M. Pinto de Azevedo, Director e António Dias, Editor.
} 


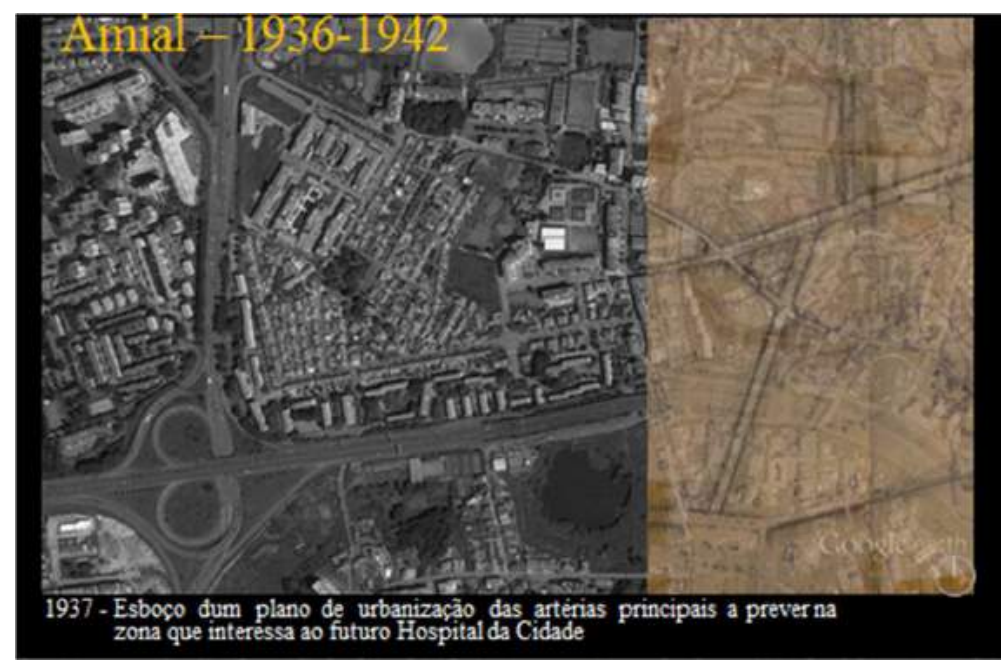

Figura 1. Fontes: Google Earth e Câmara Municipal do Porto

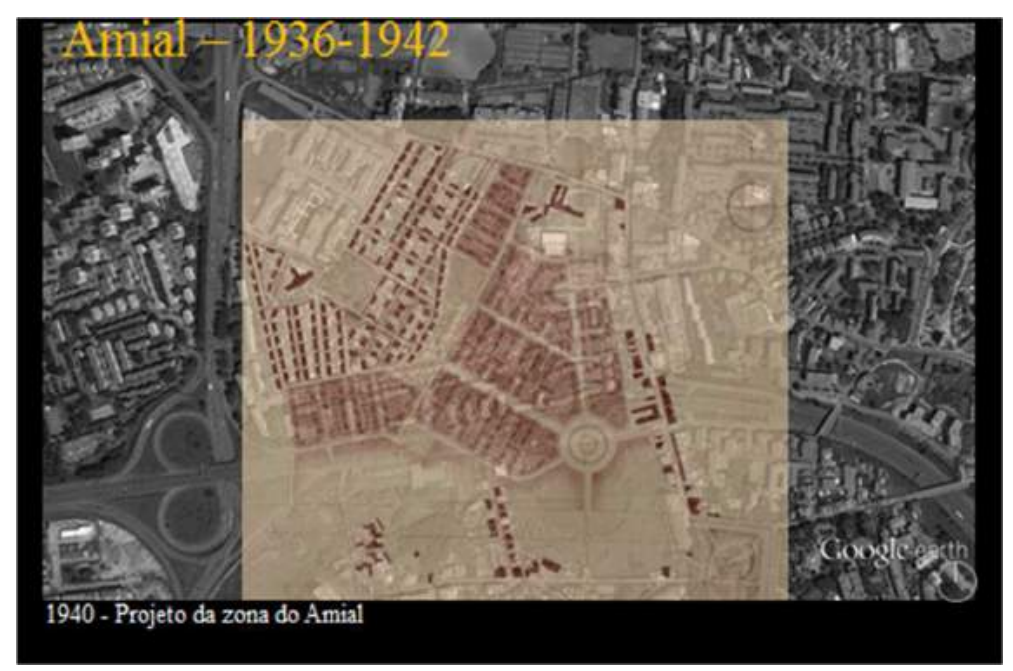

Figura 2. Fontes: Google Earth e Câmara Municipal do Porto

A morte do ministro Duarte Pacheco terá comprometido, ou, pelo menos, abrandado o processo de execução dos planos gerais de urbanização: o plano de G. Muzio para o Porto ficou no prelo. Tendo como pano de fundo a II Guerra Mundial e seus efeitos, houve atrasos na aprovação em Lisboa dos planos parcelares. Por outro lado, houve atrasos no estabelecimento das diretrizes de equipamentos de iniciativa estatal e estruturantes dos planos obrigados ao município. Ora, a vasta dimensão dos primeiros planos parcelares e as enormes dificuldades, relatadas em ata de reunião de Câmara, para a expropriação e posse de terrenos atrasaram também a expansão, prevista como fonte de verbas. Assim, acusara ainda A. GARRETT (1974), as atenções mantiveram-se na recomposição do centro urbano, ao que somaram uma aposta na densificação da malha urbana existente, por exemplo, em altura, e na habitação dos desfavorecidos na cidade. No fundo, houve uma inversão na estratégia atrás relatada. 


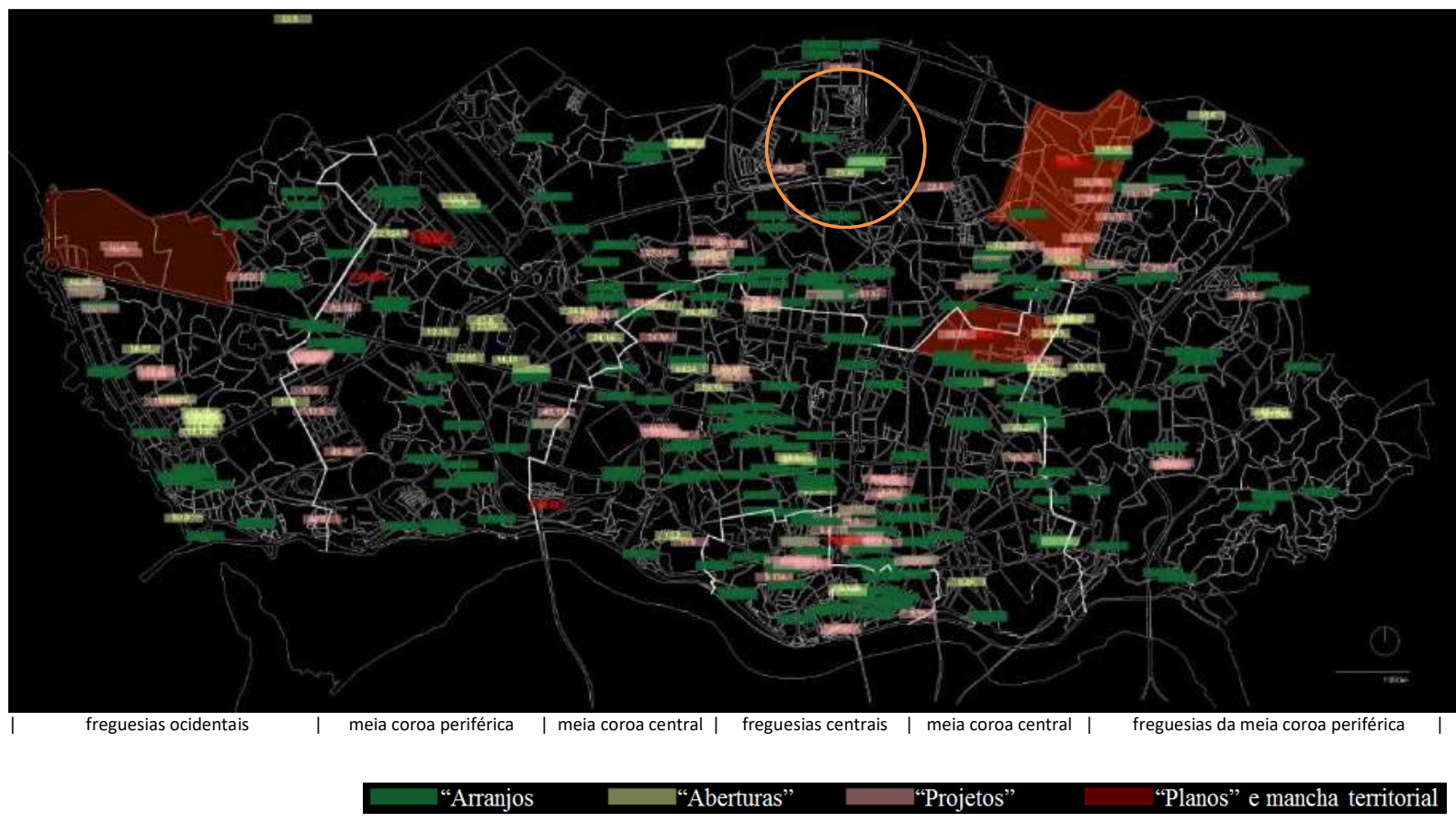

Planta 2 - Aprovações de propostas de ação urbanística no concelho do Porto, 1942-1953 (presidências de Albano Sarmento, Luís de Pina e Lucínio Prêza; “O Porto poderia ter sido uma cidade com centro-monumental e periferia-jardim"). Fonte: Vasco Cardoso, 2015, sobre planta base da Câmara Municipal da Porto.

A dinâmica do pós-guerra coincidiu com a volta na situação, começando com a aprovação do AntePlano Geral de Urbanização, em 1948, e o desbloqueio dos atrasos nos órgãos centrais. Lançado o rumo para o futuro plano geral, o Plano Regulador, retomaram os estudos de planos parcelares, contratando técnicos exteriores, em 1951: Arménio Losa para o Hospital Escolar e Januário Godinho para o Campo Alegre. Por outro flanco, viam-se em fase de conclusões os estudos sobre as formas a servir a habitação económica de diligência municipal, reforçadas com a abertura ao bloco de habitações: para a qual foram determinantes o plano de Alvalade, o I Congresso dos Arquitectos, a experiência estrangeira e, à sua escala, experiências pioneiras no Porto, como os blocos da Corujeira, S. João de Deus e Sobreiras.

De acordo com o atrás exposto, regista-se que este foi dos quatro períodos em apresentação aquele em que as aprovações do tipo "arranjos" foram em maior número. No mesmo sentido, sublinha-se que o aumento do número desse tipo por estes anos está a par dum decréscimo no número de aprovações do tipo "projetos". O que, de facto, corrobora o relatado nas atas de reunião de Câmara. Também diminuindo, as aprovações de "planos" circunscreveram-se às questões dos equipamentos desportivos e de lazer, alinhando ainda numa perspetiva de cativar visitantes turistas. A questão do estádio municipal e/ou do Futebol Clube do Porto uniu no problema a procura de resolução dos terrenos cativados, pelo menos desde 1926, no ocidente da cidade, entre a Avenida da Boavista e a Estrada da Circunvalação. A nortada afastou essa hipótese e trouxe o projeto para a Areosa, a norte, em reformulações do primeiro plano, até ao abandono, em favor das Antas, por menos ambicioso. 
Foi precisamente às Antas, pelo campo do Lima, onde Arménio Losa foi responsável pela proposta de blocos de habitação de rendimento ${ }^{7}$, num momento em que o modelo de cidade-jardim era ainda defendido, em 1945. Por essa data, o mesmo urbanista, também da resolução das praças e ruas na baixa, propôs uma solução moderna no centro monumental da cidade, nos Leões, sobre pilotis e com pátio interior semipúblico ${ }^{8}$. A planta 2 e a figura 3 referem-se ao período descrito.

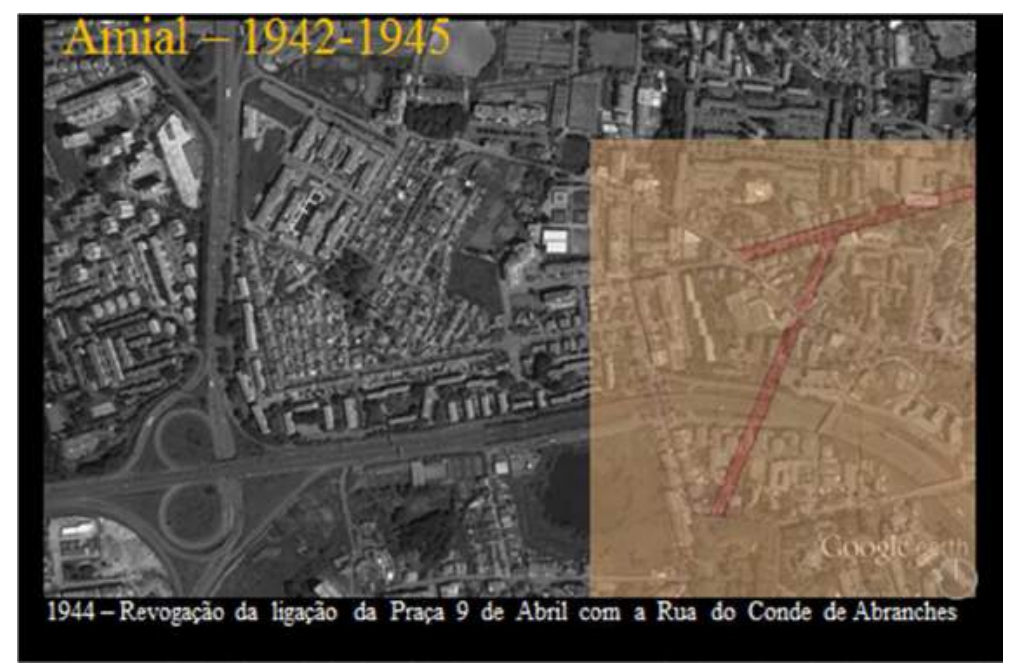

Figura 3. Fontes: Google Earth e Câmara Municipal do Porto

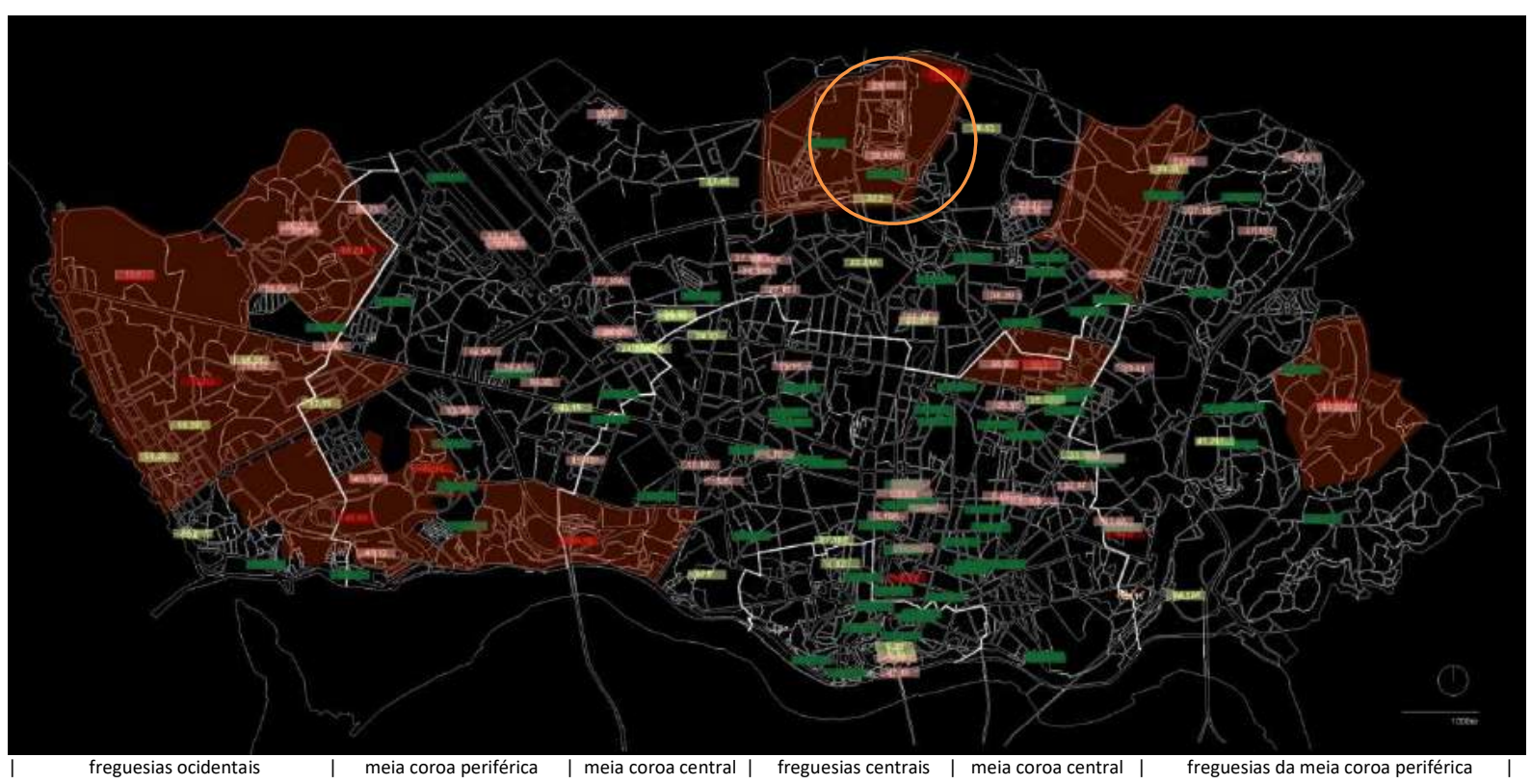

Planta 3 - Aprovações de propostas de ação urbanística no concelho do Porto, 1953-1962 (presidência de Machado Vaz; "O Porto poderia ter sido uma cidade de conjuntos filiados na Carta de Atenas"). Fonte: Vasco Cardoso, 2015, sobre planta base da Câmara Municipal da Porto.

\footnotetext{
7 Projeto 711 - "Plano Parcial de Urbanização a Sul da Antas limitado pela Avenida dos Combatentes da Grande Guerra, pelas Ruas da Alegria e de Carlos Malheiro Dias e pelo prolongamento da Avenida de Fernão de Magalhães"

8 Projeto 163-A, “Projeto de Alinhamentos para o lado Norte da Praça de Gomes Teixeira”, 14/6/1945.
} 
A urbanização da expansão começaria, para o final do período, a seguir nos planos parcelares reabilitados no espírito da Carta de Atenas. No sempre atendido centro da cidade, a entrada para a vereação do reputado Manuel de Figueiredo trouxe a defesa da valorização do património, pelos conjuntos monumentais no centro. Estes foram três motes do próximo futuro desejado.

Como atrás referido, este período arrancou com a efetividade dos planos gerais e parcelares. Se o Plano Regulador marca o primeiro registo regulado legalmente e se os planos parcelares que decorriam e foram sendo revistos e redesenhados - reformulando - funcionaram como cadinho do pensamento sobre urbanismo e forma urbana, enquanto o gabinete técnico municipal maturava, sob a coordenação de Robert Auzelle, então, o Plano de Melhoramentos foi o meio operacional da transformação urbana do Porto, como desenvolveu A. CARDOSO (1990).

Apoiada no novo regime de expropriações, no novo REGEU e no novo Plano de Fomento, e dotada do conhecimento municipal acumulado de vários anos sobre habitação económica, a Câmara conseguiu resolver o impasse em que a estratégia lembrada por A. GARRETT, atrás trazida, entrou. Em primeiro lugar, atente-se em que uma das metas do urbanismo do período do Estado Novo foi a chamada granulometria social: pretendiam uma presença equilibrada de pessoas de diferentes origens sociais e económicas para habitar os espaços a urbanizar - além de, assim, poderem providenciar diferentes ofertas, claramente acreditavam evitar confrontos. A. GARRETT trouxe este desígnio para o Plano Regulador integrado no conceito de Unidades Residenciais, com lastro nas Unidades de Vizinhança americanas. Em segundo lugar, verificou-se que a distribuição dos grupos de moradias populares $^{9}$ seria feita por terrenos sobrantes, menos favoráveis para a construção, ou, ainda, por custos muito vantajosos, essencialmente, pelas freguesias da aqui designada meia coroa periférica. Essa coroa estruturar-se-ia na Avenida de Circulação Interna, a qual foi integrando o rumo da antiga via de atravessamento pela Arrábida, tendo-se transformado numa via rápida de circulação e distribuição do trânsito pelo interior do concelho e de onde radiariam as vias rápidas de relação com o exterior. Ora, complementando a estratégia, procuravam que aqueles assentamentos contiguassem com outros preexistentes, ou com terrenos destinados à implantação de equipamentos públicos, ou deixassem a orla do terreno reservada à exploração de rendimentos urbanísticos. Para todos estes casos de assentamentos vizinhos houve uma aprovação de tipo "projeto" e, a partir deste período, fez crescer para o máximo o número deste tipo, reduzindo-se, consequentemente, as aprovações de ações pontuais.

Daquele modo, a granulometria social, que anteriormente deveria por força ser garantida no território vasto dos primeiros planos parcelares de urbanização, de onerosa e complexa expropriação e posse, passaria a ser conseguida à medida das possibilidades de terrenos, procurando dispor em função da infraestruturação existente e na vizinhança de outras formas. Esta foi a prática que ditou a revisão dos antigos planos parcelares em novos, a caminho do Plano Director.

\footnotetext{
${ }^{9}$ Blocos multifamiliares de habitação em altura de, habitualmente, 3,4 ou 5 pisos, construídos formando conjuntos, mais ou menos extensos, em função dos terrenos disponíveis, no âmbito do Plano de Melhoramentos.
} 
A urbanização da expansão utilizava formas e estratégias no espírito da Carta de Atenas. No centro da cidade o foco deslocara-se para norte, depois da Avenida dos Aliados, levando o principal cruzamento de vias cardiais. Por lá, desejaram grandes volumetrias, muitas ocupando o lugar de várias ilhas, no rumo da construção de uma cidade centro do terciário de uma região A planta 3 e figuras 4 a 8 revelam sobre o período mencionado.

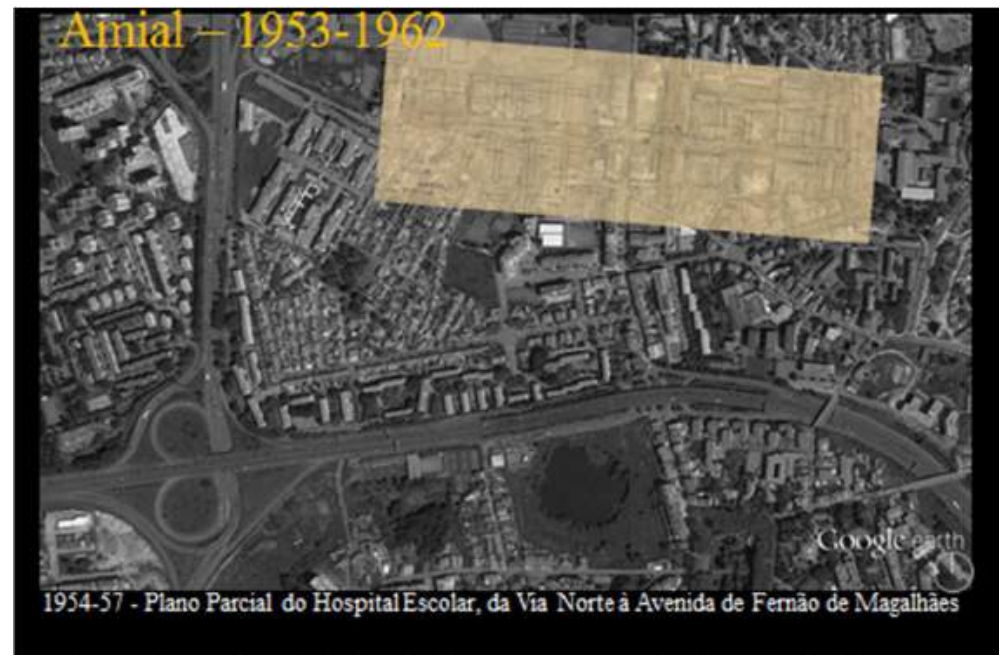

Figura 4. Fontes: Google Earth e Câmara Municipal do Porto

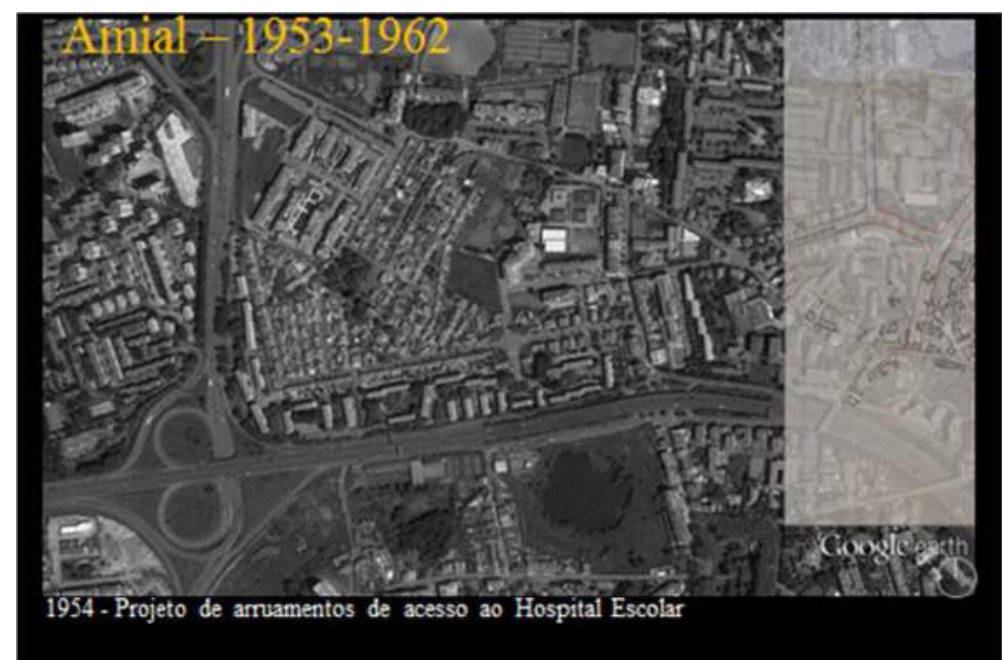

Figura 5. Fontes: Google Earth e Câmara Municipal do Porto 


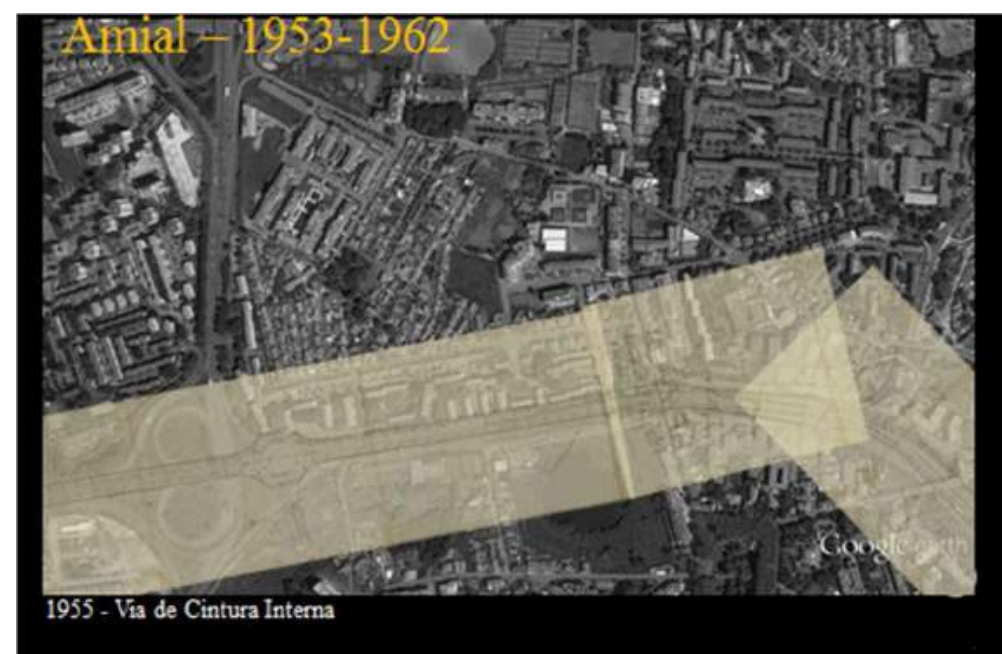

Figura 6. Fontes: Google Earth e Câmara Municipal do Porto

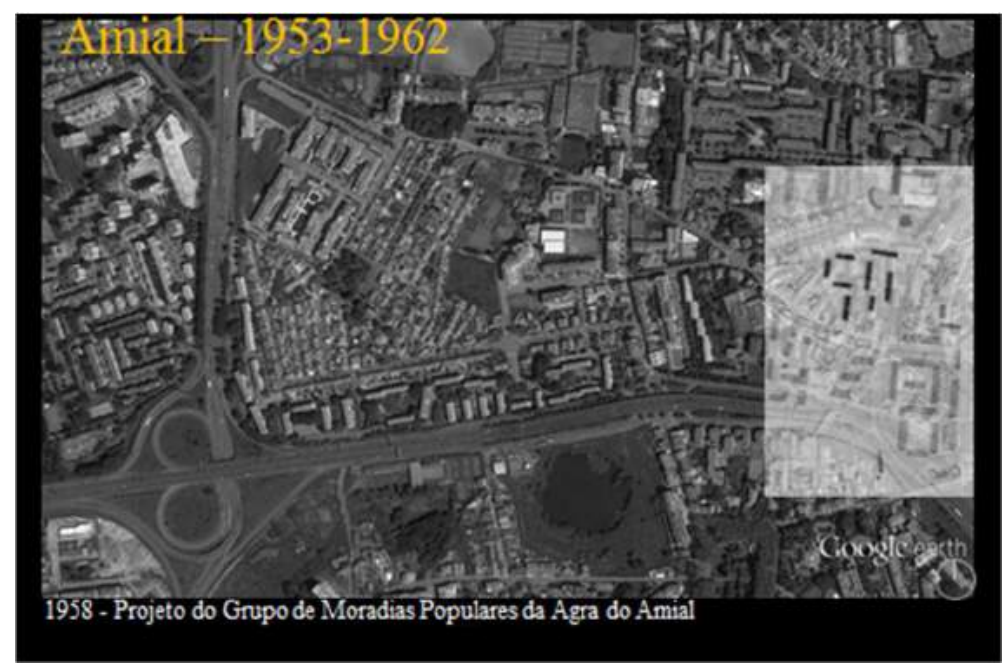

Figura 7. Fontes: Google Earth e Câmara Municipal do Porto

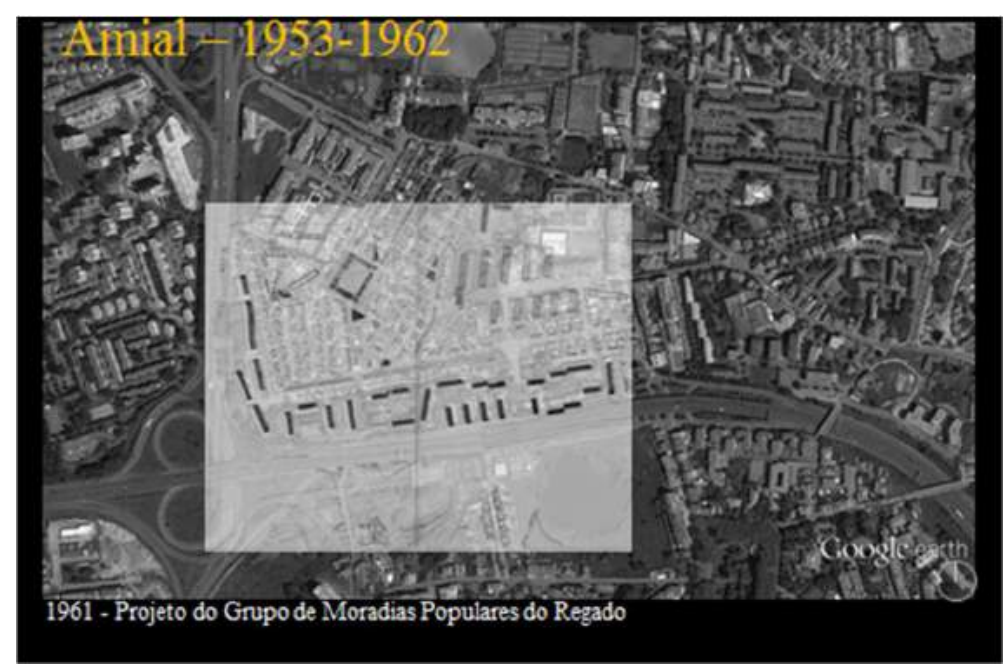

Figura 8. Fontes: Google Earth e Câmara Municipal do Porto 


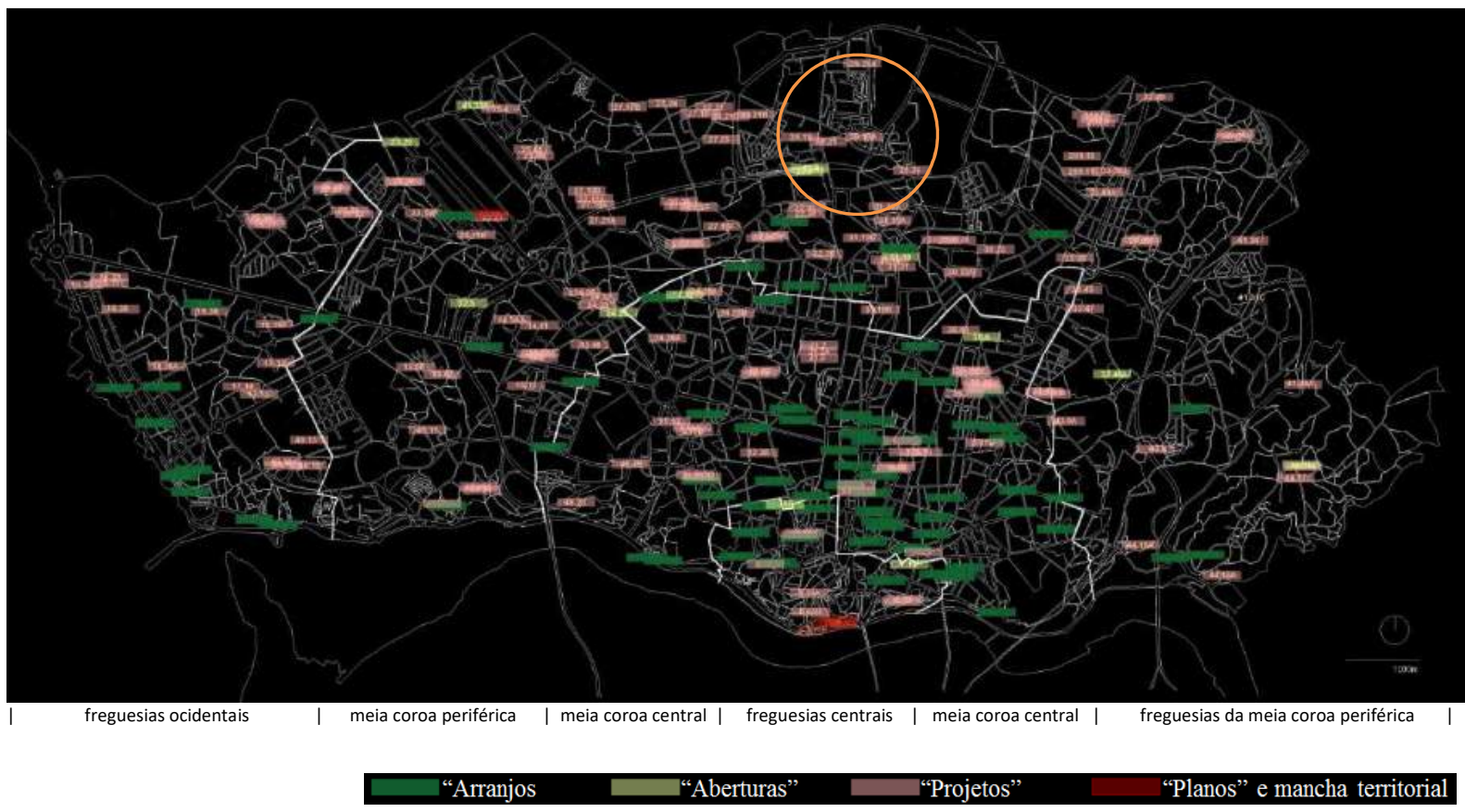

Planta 4 - Aprovações de propostas de ação urbanística no concelho do Porto, 1962-1974 (presidências de Pinheiro Torres e Vasconcelos Porto; “O Porto poderia ter sido cedo uma cidade de empreendimentos e ímpeto regional"). Fonte: Vasco Cardoso, 2015, sobre planta base da Câmara Municipal da Porto.

O futuro desejado durante o período passado foi em parte consolidado por esta época.

Este período é caracterizado pelas aprovações do tipo "projetos". Estes distribuíram-se em maior número do centro para a periferia do concelho, precisamente pelos locais que receberam os planos parcelares. Estabilizados os planos parcelares, os "projetos" orientaram-se por eles, e remodelaramnos. De facto, não se poderá concluir que esses "projetos" adviessem dos "planos". Na verdade, muitos planos parcelares de urbanização coligiram vários espaços onde houvera estudos e integraram-nos, reformulando-os. Outros espaços dentro do campo de ação dos planos parcelares estavam destinados à implantação de equipamentos públicos de iniciativa municipal ou estatal e distribuídos pelo concelho, obrigando a aprovações do tipo "projeto" para urbanizar esses terrenos.

No quadro acima descrito cabem também os novos grupos de moradias populares, da prorrogação do Plano de Melhoramentos, até ao seu desvanecimento para o final deste período.

Um outro aspeto marcante para o relevo dos "projetos" e com mais peso na segunda presidência deste período é aquilo que poderá ser lido como os futuros desejados de vários investidores privados, protagonistas de muita da construção de forma urbana por estes tempos. Com base legal dada pelo novo plano geral de urbanização, o Plano Director, e pelo regime da propriedade horizontal, apresentaram diferentes propostas de urbanização de terrenos de antigas propriedades rurais pela margem do concelho, ou de antigas propriedades urbanas por mais próximas da mancha construída. O porquê da hipótese de leitura acima lançada encontra-se no facto de estas propostas de urbanização, apesar de privadas, passaram pela aprovação prévia do arquiteto e urbanista consultor, Robert Auzelle. Antes de visar os projetos, o urbanista produzia apreciações escritas e desenhadas que os condicionavam. Participando, a Câmara aprovava-os na sua reunião. 
Essas iniciativas visadas seguiram uma linha morfológica na esteira do que J. M. R. G. LAMAS (2007) chamou de urbanismo operacional, muito comummente no Porto das freguesias da meia coroa periférica e nas freguesias ocidentais expressa por bandas construídas pela periferia dos terrenos e com blocos e torres no interior. Da mesma família, a solução morfológica utilizada pela cidade mais compacta expressava-se de dois modos. No caso de urbanização de antigas quintas, ocupavam o interior com blocos e/ou torres e preservavam o possível dos jardins, como na Avenida Brasil, na Foz do Douro, ou na Rua de Oliveira Monteiro, em Cedofeita. No caso de urbanização de espaços no remate ou ocupação de antigos e largos quarteirões, destinavam ao interior as volumetrias mais autónomas e pela periferia procuravam manter as volumetrias de menor cércea, construindo bandas à face do quarteirão. Contudo, com diferentes afastamentos ao eixo da via, criavam baias de estacionamento: efeito de degradação de volumes, argumentado pelos técnicos camarários nos projetos dos grupos de moradias populares da década de 1960. Este efeito foi relevante nas vetustas estradas reais radiais da cidade à Póvoa - Rua de Monte dos Burgos - e a Braga - Rua de Costa Cabral.

A uma dimensão mais global para o novo futuro desejado, o poder municipal, dinamizado pelas intervenções, em grande número, dos vereadores do final deste período, pugnava pelo planeamento regional, com o Porto como centro de uma região. Para tal, os projetos lançados no período passado para a área a norte do centro da cidade concretizavam esse objetivo em forma urbana. Mas, a expressão do objetivo passava, na defesa que lhe faziam, também por questões como parques verdes regionais, o metro de superfície, o aproveitamento das margens do Douro, entre outras As figuras de 9 a 17 ilustram a época atrás descrita com o exemplo escolhido do Amial.

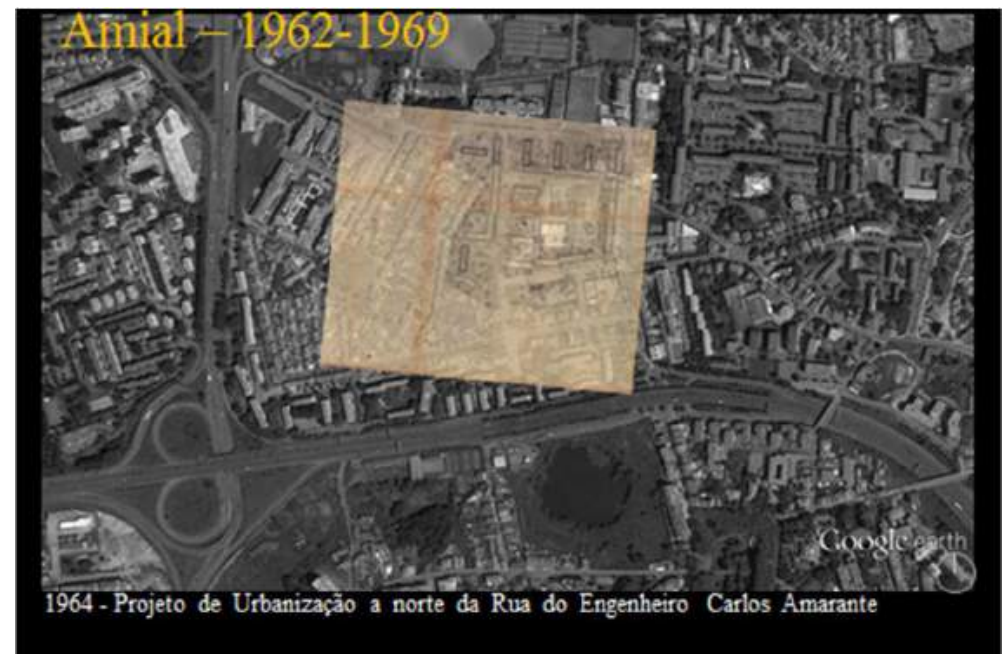

Figura 9. Fontes: Google Earth e Câmara Municipal do Porto 


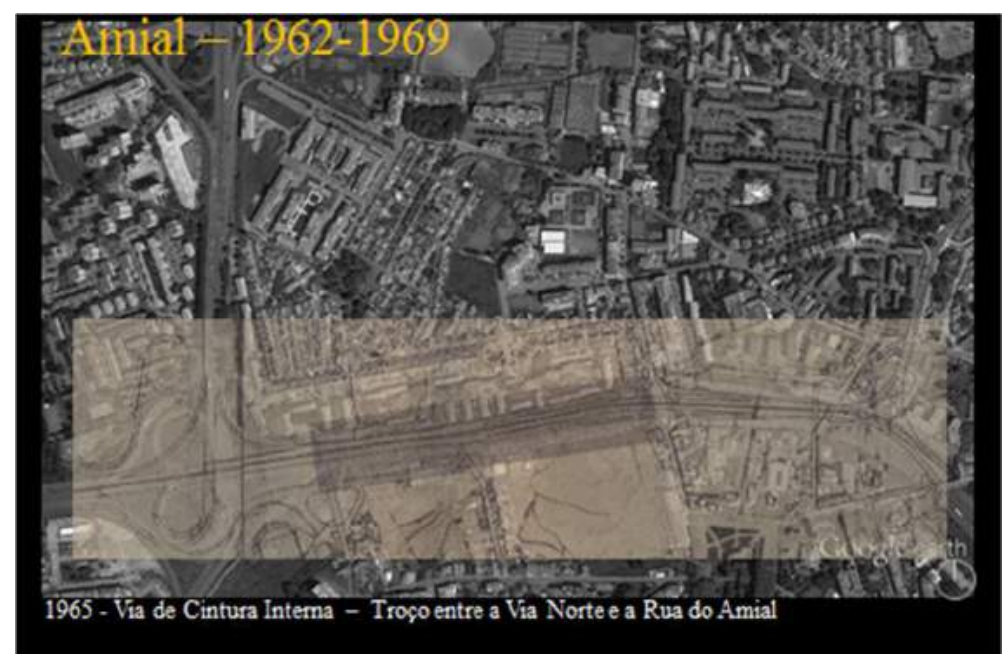

Figura 10. Fontes: Google Earth e Câmara Municipal do Porto

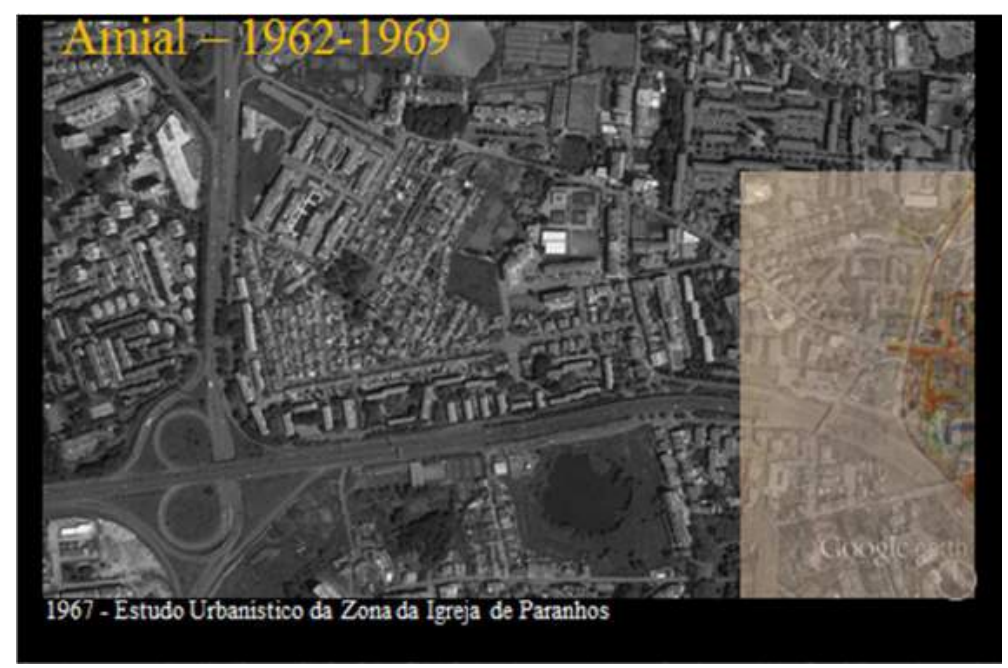

Figura 11. Fontes: Google Earth e Câmara Municipal do Porto

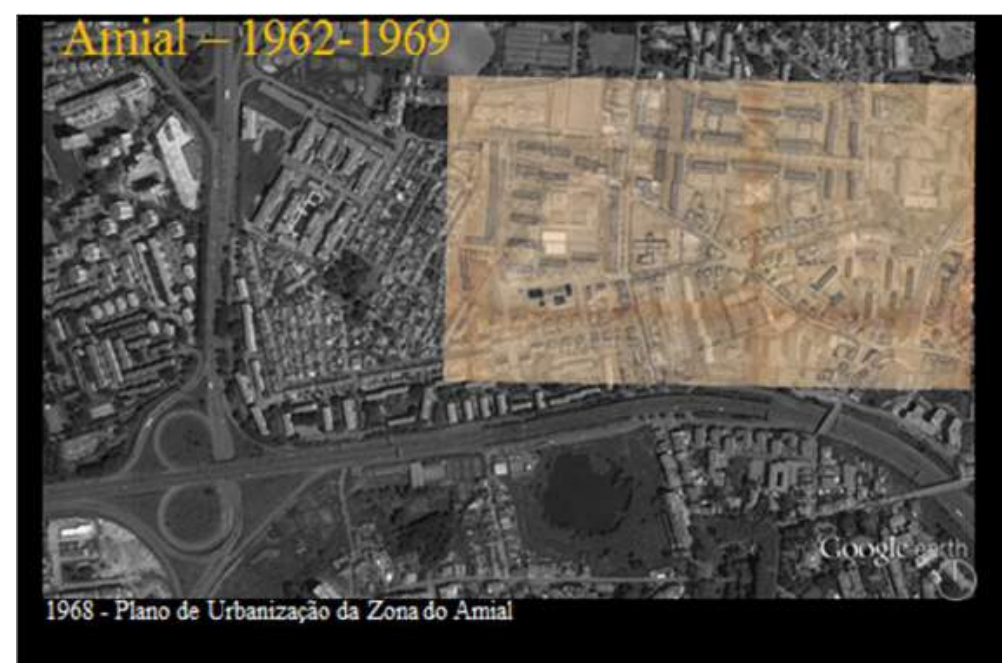

Figura 12. Fontes: Google Earth e Câmara Municipal do Porto 


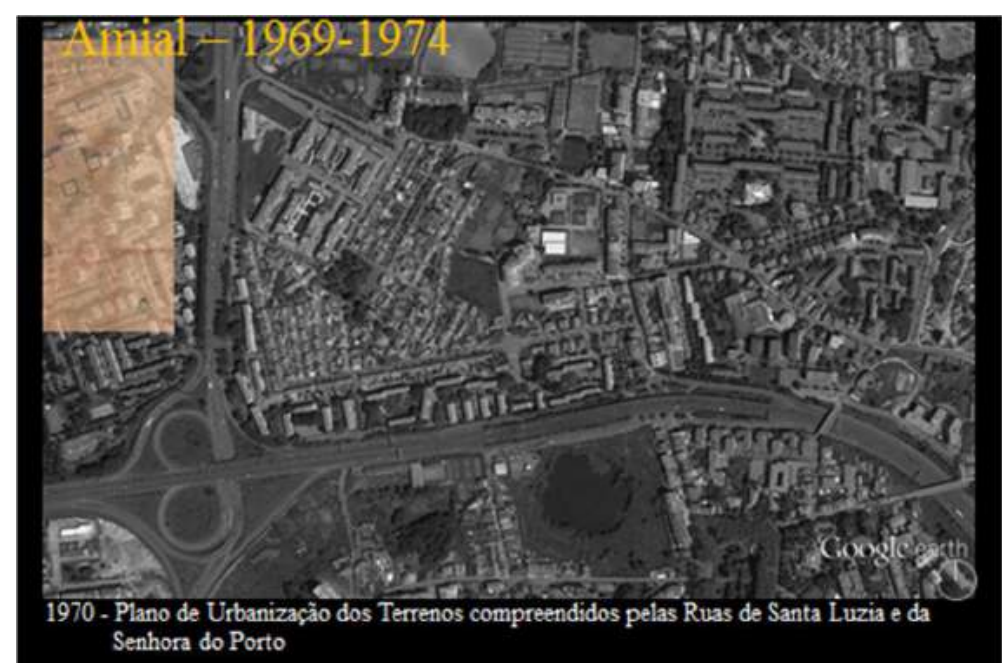

Figura 13. Fontes: Google Earth e Câmara Municipal do Porto

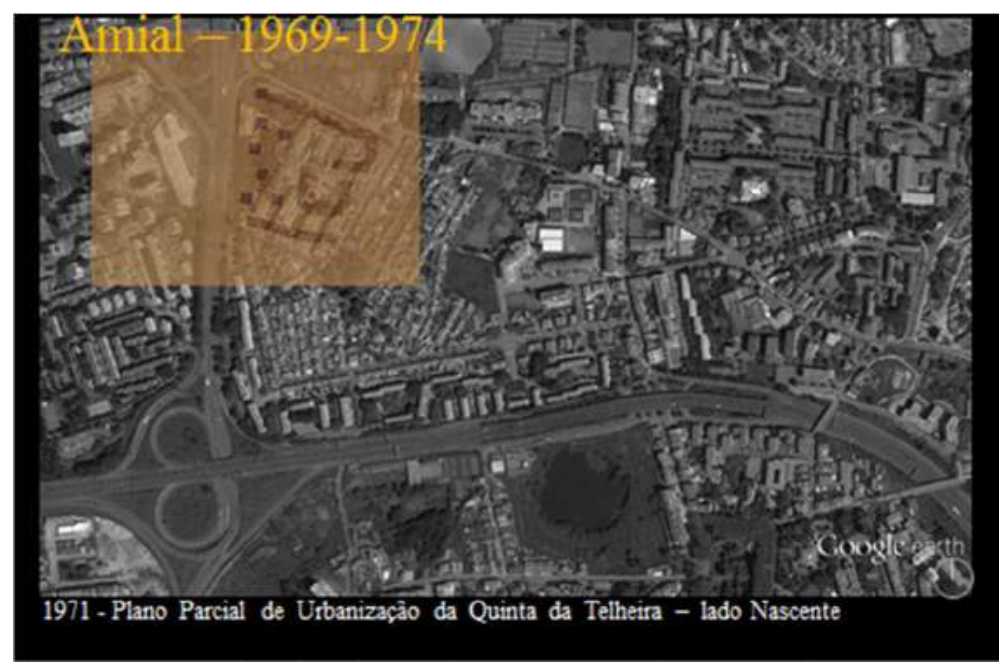

Figura 14. Fontes: Google Earth e Câmara Municipal do Porto

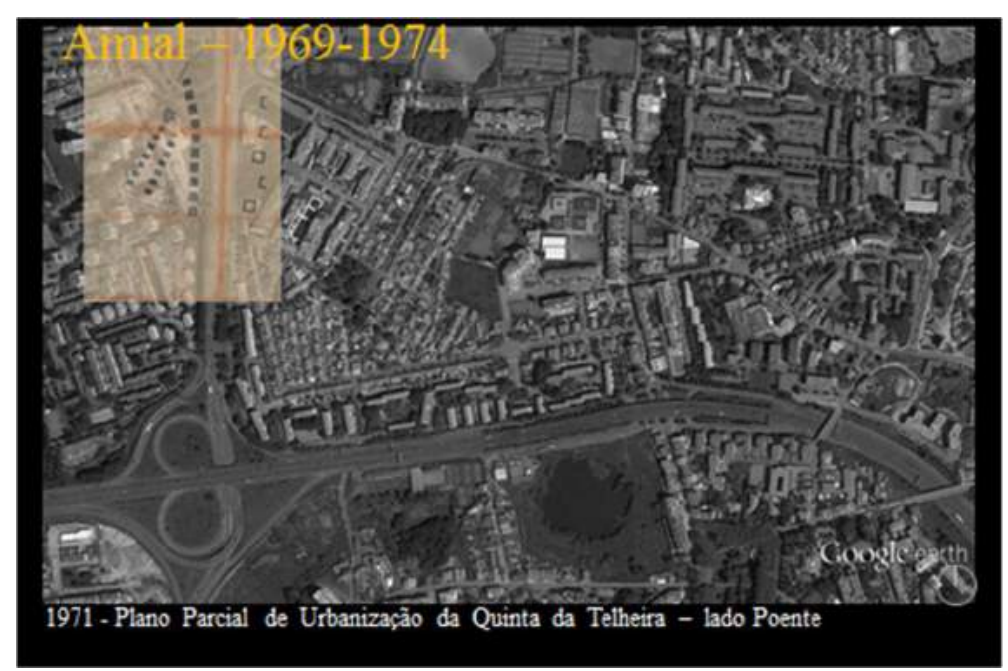

Figura 15. Fontes: Google Earth e Câmara Municipal do Porto 


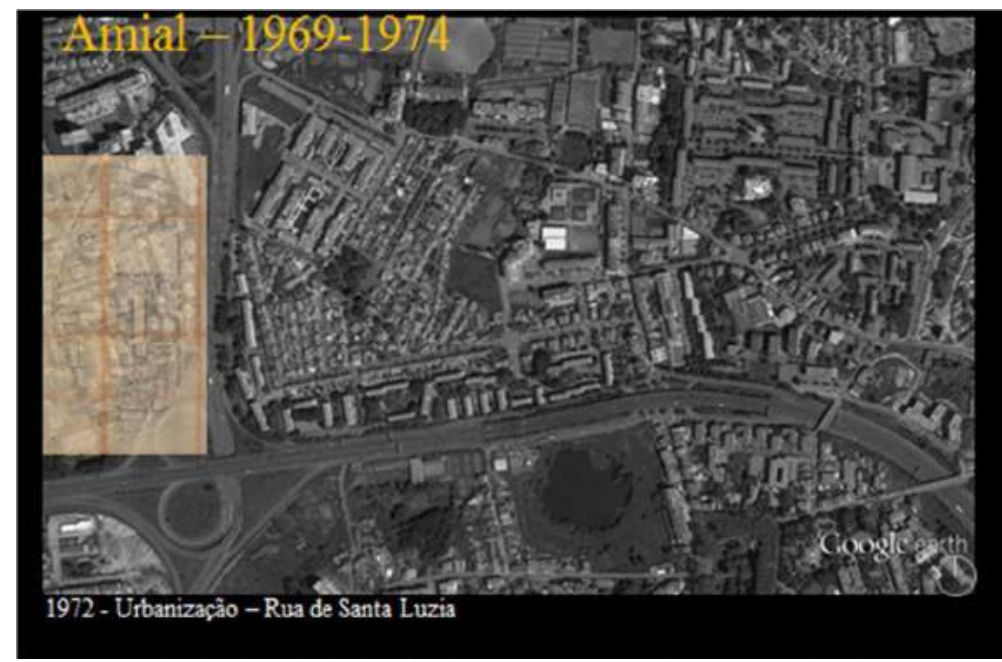

Figura 16. Fontes: Google Earth e Câmara Municipal do Porto

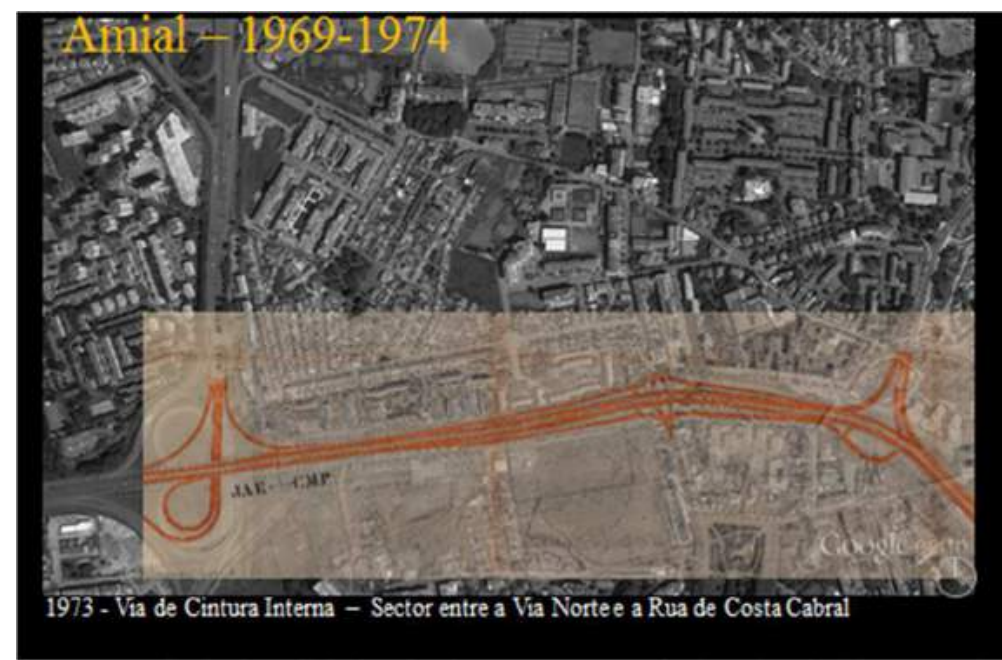

Figura 17. Fontes: Google Earth e Câmara Municipal do Porto

\title{
5. Conclusões
}

\begin{abstract}
“A relação entre os espaços especiais e as razões urbanas que lhes deram origem ou que promoveram o seu desenvolvimento é de tal modo solidária que a maioria das vezes permanece compreensível, mesmo depois de essas funções cessarem. A mudança radical do papel urbano de um espaço origina, no entanto, alterações formais resultantes de novos significados." C. D. COELHO (2007)
\end{abstract}

A citação acima importa pelo que para aqui aporta da pertinência da Morfogénese Urbana e da relevância da relação da parte com o todo na forma urbana. No Porto da época debatida, em que a forma surgiu ou se transformou de iniciativas mais condicionadas e por vários escolhos, o plano de 
pequena dimensão foi preponderante. Nomeadamente, foi-o para se entender o vínculo entre o processo de tomada de decisão política e a forma urbana, no sentido da senda por futuros desejados.

A metodologia de estudo da forma urbana e sua génese que procurou uma análise àquela escala terá desvendado vertentes da origem e maturação das formas que, crê-se, a uma escala de plano geral de urbanização poderiam ser menos nítidas. Por outro lado, os momentos em que mais se conheceu dos futuros desejados não coincidiram com os das aprovações dos planos gerais. Contudo, por complemento, o recurso à análise em várias escalas foi tido. No desenvolvimento deste trabalho investigativo, a promitente dinamização informática dos seus resultados poderá ampliar o número de faces de leitura da forma urbana e sua génese aqui em debate.

Tal como o trabalho de doutoramento, este texto também deseja seguir "...[autores] que, ponderando aspectos culturais, sociais, económicos e políticos, apostam na abordagem morfogenética como metodologia de conhecimento da morfologia urbana..." (M. G. FERNANDES, 2010). Nesse rumo, verificou-se ser possível conseguir bem aclarar sobre o estudo do desejado no passado. Entre outros aspetos, sobre: quem deseja, o conhecimento das referências presentes no pensamento de quem deseja, a influência dos contextos de cada tempo na formulação dos então futuros desejados e o percurso dos desejos formulados face à dinâmica da circunstância e do modo como se formularam esses desejos. Além desses aspetos, o estudo do desejado está diretamente implicado na avaliação, nomeadamente pela aprendizagem retirada do confronto entre o que foi sendo desejado e o que foi realmente conseguido.

Pretendeu-se apresentar a metodologia utilizada na investigação de doutoramento, através de exemplos de aplicação localizados, e, assim, contribuir para a reflexão da sua possível aplicabilidade no estudo do passado dos futuros desejados na forma urbana. Contudo, face a um presente de uma realidade urbana facetada, em constante mudança, um espaço de pluralidade de múltiplos sujeitos com direito e dever de participar nas políticas públicas, terá também pertinência para esse tempo, na idealização, a metodologia seguida.

A construção de novos futuros desejados, neste caso para as políticas públicas sobre urbanismo e forma urbana, deverá ser permeável à contribuição trazida por uma visão retrospetiva, e bem contextualizada, daquilo que já foi desejado.

\section{Referências bibliográficas}

ALMEIDA, P. V. d. A Arquitectura no Estado Novo, uma leitura crítica - Os Concursos de Sagres. Lisboa: Livros Horizonte, 2002.

BASTO, M. Nota introdutória da Secção Cultural da Câmara Municipal do Porto, in Boletim Municipal, Câmara Municipal do Porto, Porto, Ano 1, 1936, n.o 37, p. 517.

BASTO, M. "Falam Velhos Manuscritos... MELHORAMENTOS URBANOS...DO SÉCULO PASSADO”, in O Primeiro de Janeiro, Ano 78, 1946, n.o 10, de 11 de setembro de 1946, p. 1. 
CARDOSO, A. De ponte a ponte: o processo de urbanização da área metropolitana do Porto desde os anos cinquenta. Porto: Ministério do Planeamento e da Administração do Território, Comissão de Coordenação da Região do Norte, 1990.

CARDOSO, V. Morfologia urbana nas "freguesias mais exteriores». In Atas do Simpósio Luso-Brasileiro de Cartografia Histórica - Territórios: Documentos, Imagens e Representações, Porto: FLUP, 2011

CARDOSO, V. Morfologia Urbana no Porto de 1936 a 1974. Tese de Doutoramento, Faculdade de Letras da Universidade do Porto, Porto, 2015 (a).

CARDOSO, V. As cidades que o Porto poderia ter sido. In Atas do VI Simpósio Luso Brasileiro de Cartografia Histórica. Braga, 2015 (b).

COSTA, M. L. Os SIG e a Cartografia Histórica Urbana. Dissertação de Mestrado, Faculdade de Letras da Universidade do Porto, Porto, 2015.

FERNANDES, J. A. V. R. e SPOSITO, M. E. B. (org). A nova vida do velho centro nas cidades portuguesas e brasileiras. Porto: CEGOT, 2013.

FERNANDES, M. G. (2005). Urbanismo e morfologia urbana no Norte de Portugal. Viana do Castelo, Póvoa de Varzim, Guimarães, Vila Real, Chaves e Bragança. 1852/1926. Porto: FAUP Publicações.

FERNANDES, M. G.. O estudo da morfologia urbana em Portugal. In XII Colóquio Ibérico de Geografia, Porto, 2010.

GARRETT, A. A. História da Evolução dos Planos Gerais de Urbanização da Cidade do Porto. Porto: FEUP, 1974

LAMAS, J. M. R. G.. Morfologia Urbana e Desenho da Cidade (4. ed.). Lisboa: Fundação Calouste Gulbenkian, Fundação para a Ciência e Tecnologia, 2007.

LAMAS, J. M. R. G., COELHO, C. D. (Eds.). A Praça em Portugal. Inventário do Espaço Público: Continente. Lisboa: D.G.O.T.D.U., 2007.

LÔBO, M. S.. Planos de Urbanização, A época de Duarte Pacheco. Porto: FAUP Publicações, 1995.

OLIVEIRA, J. M. P. O espaço urbano do Porto - condições naturais e desenvolvimento. Porto: Edições Afrontamento, 2007, 1. Ed de 1973.

VETCH, P., et al.. Between text and image: digital renderings of a late medieval city. In B. NELSON, M. TERRAS (Eds.), In Digitizing Medieval and Early Modern Material Culture. (New Technologies in Medieval and Renaissance Studies; Vol. 3). Tempe, Arizona: Arizona Center for Medieval and Renaissance Studies, Arizona State University, 2011, pp. 365-396. 